\title{
Positions and Roles of Agricultural Extension Workers in Poultry Egg Marketing in Delta State, Nigeria
}

\author{
Ovwigho B. 0. \\ Isiorhovoja, R. A. \\ Idoge, D. E \\ Department of Agricultural Economics and Extension, Delta State University, \\ Asaba Campus, Asaba, Nigeria
}

\section{Doi:10.5901/mjss.2014.v5n2p197}

\section{Abstract}

The broad objective of the study was to describe the role of agricultural extension workers in the marketing of poultry eggs. A sample of one hundred and five (105) enterpreneurs of small and medium scale poultry farms and forty seven (47) extension workers was randomly composed.. The marketing channel for poultry eggs consisted of the producers, middle men/assemblers, wholesalers, retailers and consumer. The most important stages for advising farmers on egg marketing were the laying and packaging stages. There was a significant difference between total scores on role perception and role performance scores on the eleven (11) extension roles in egg marketing $(t=19.892 ; p<0.01)$. In particular, a significant difference between role perception and performance was found in the advisory services on egg grading $(t=3.749 ; p<0.01)$, advise on available markets for poultry eggs $(t=8.233 ; p<0.01)$, and provision of price information $(t=6.095 ; p<0.01)$. The role of extension workers in poultry egg production should go beyond the traditional transfer of proven layers to encompass the various egg marketing functions in order to improve the welfare of the poultry egg producers.

Keywords: Marketing channel, Marketing Extension, Extension Workers, Role Perception, Role Performance

\section{Introduction}

\subsection{Background Information}

The old definition of the term market as a place where buyers and sellers meet to exchange money, goods and services is no longer tenable under the present-day globalisation and liberalisation of trade and services. It is exigent to define a market as a two-way communication process which leads to agreement between a buyer and seller on the transfer of title of goods and, eventually, the physical movement of the goods (Fig. 1).

Fig. 1: Two-way Communication Process in Marketing

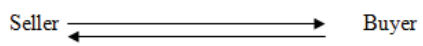

In the past buyers and sellers must meet in a particular market place in order to purchase goods and services. Nowadays, in matter of minutes or hours a buyer in Kenya can perfect transaction on agricultural commodity in London, US, Japan, Germany, Nigeria or South Africa through telephone call and/or internet services. CTA (2007) found that a woman in Ghana could receive prices from 380 African markets for her products through the cell phone. She noted that the GSMs provided farmers with real-time agricultural commodity prices. They enabled farmers make informed decisions on which crops to grow and when to sell their products for best returns.

Agricultural marketing is intrinsic to the variegated processes and procedures for marketing agricultural produce. Mohammed et.al. (2013), and Adegeye and Dittoh (1982) compartmentalised agricultural marketing as the stages of operation which aid the movement of agricultural commodities from the farms to the consumers. The stages include assemblage of goods, storage, transportation, processing, grading and financing of these activities. Adegeye and Dittoh (1982) summarised the importance of agricultural marketing as follows: 
- It constitutes a process of moving agricultural produce to the consumers and urban markets.

- Ensures efficiency in the marketing of agricultural produce. An efficient agricultural marketing system also assists in the exportation of agricultural produce.

- It enables the farm firm to identify the consumer preferences based on the prices they are willing to pay. This in turn affects the production decision of the farmer.

- Stimulates research into techniques of food and meat preservation and preparation.

- It makes seasonal foods to be available all year round with little variation in costs due to storage.

Marketing channel refers to the stages which goods and services usually pass through before reaching the final consumer. Marketing channels varies according to the type of goods and services involved. Adegeye and Dittoh (1982) drew a generalised marketing channel for food stuff in Nigeria (Fig. 2). It starts with the producer and ends with the final consumer in a sequential order. The changing roles of agricultural extension services demands that extension agents should have knowledge of the channel agricultural produce passes until it gets to final consumer in order to identify areas of enhancing the farmers income. CTA (2003) averred that the conventional way of selling products at the farm gate was gradually being replaced with structured trading especially in eastern and southern Africa. Structured trade was an outcome of market liberalization surge in the late 1980s.

According to Swanson (2008), the term agricultural extension has changed over times. It is no longer restricted to the emphasis on technology transfer reflected by the Training and Visit ( $T$ \& V) System but has moved towards broader concepts which include developing the skills and management capacities of farming families. Extension helped to facilitate the access of farmers, their organisations and other market actors to knowledge and technology, and facilitate their interaction with similar organisations.

CTA (2011) and USAID (2011) maintained that extension and advisory services were designed to help farmers boost crops and livestock production. These services enable farmers to adopt new technologies for increase production and profitability. According to them the specific objectives of agricultural extension and advisory services were to:

i. provide advice to farmers on problems or opportunities in agricultural production, marketing, conservation and family livelihood;

ii. facilitate development of local skills and organisations, and to serve as links with other programmes and institutions;

iii. transfer new technologies to farmers and rural people; and

iv. address public interest issues in rural areas, resource conservation, health and food security, monitoring agricultural production,, monitoring food safety, nutrition and family education as well as youth development. Swanson and Rajalahti ( 2010) stated that the traditional technology transfer model of extension was prevalent only during colonial times. Ovwigho and Ifie (2009) stated that agricultural extension encompass transfer of technology, youth extension programme, social development and home making, rural youth extension programme, and health care and hygiene. This definition is broader in perspective than the traditional definition of agricultural extension germane to transfer of technology.

The changing role of agricultural extension delivery calls for an in-depth investigation of the extent to which it has embraced advisory services on the marketing of agricultural products. This study is, therefore, designed to investigate the positions and role of agricultural extension services in the marketing of poultry eggs in the study area.

\subsection{Statement of the Problem}

Agricultural extension has continued to advance in terms of activities rendered to farmers. The traditional transfer of proven technologies can no longer satisfy the yearnings and aspirations of the farmer particularly the small-scale rural farmers. They need advisory services on home economics, marketing, decision making, leadership, nutritional practices, general education, credit and credit moblisation as well as health care and hygiene practices. FAO (2013) admonished that as farmers become more market oriented, so extension workers need to be in a position to advise them not only on how to grow crops but also on how to market them. Knowledge of produce handling, storage and packaging was essential to the performance of the farmer in his farming business.

Marketing of agricultural products in most developing countries is dominated by middle men who, in most cases, are richer than the producers. Olaitan (1984) observed that the village farmers who produce the crops sold in urban markets, towns and villages were usually very poor. He remarked that the middlemen appear to be wealthier hence it was financially preferable to be a distributor of farm produce rather than a producer.

Mohammed et. al (2013) and FAO (2013) found that the major problems of poultry egg marketing were price 
fluctuation, poor sales, lack of capital, poor record keeping, handling, distribution and transportation. They observed that though nature has given the egg a natural package - the shell, the egg remains an extremely fragile product and even with the best handling methods, serious losses can result from shell damage. Economical marketing generally requires that eggs be protected by the adoption of specialized packaging and handling procedures.

The conventional approach to extension delivery in the study area further compounds the problems of marketing extension. The approach lays emphasis on technology adoption instead of driving changes that could radically transform the standard of living of the rural farm families. Ogunfiditimi and Ewuola (1995) stated that the conventional or ministry type of extension system was characterized by bureaucracy and a top bottom approach. They emphasized that the topbottom approach has a command posture of either 'take it or leave it'. It is further characterized by duplication of organisation and services, conflicting messages, lack of focus, vague job description if any, poor logistics support, ineffective supervision, staff frustration and lack of clientele involvement in programme development.

Benson and Jafry (2013) suggested the practical needs of adopting alternative approaches to extension, especially in the context of poverty alleviation. They mentioned the challenges of reforming extension to act as a facilitator and an enabler, rather than as mere service provider, and explained the difficulties in moving towards reforms that promote pluralism and innovation Ozowa (1997) stated that a lot needed to be done in the area of agricultural extension marketing in Nigeria. From all indications extension marketing is a new extension approach for improving the farmers' incentives from his agricultural production endeavour. The study sought to re-position the role of agricultural extension in the marketing of agricultural products with particular attention to poultry egg marketing. The broad objective of the study was to describe the role of agricultural extension workers in the marketing of poultry eggs. The specific objectives were to (i) describe the marketing channel for poultry eggs; (ii) map the positions of agricultural extension workers for providing marketing extension services; (iii) examine the perception of extension workers role in poultry egg marketing; (iv) ascertain the performance of extension workers in poultry egg marketing; (v) test the congruency between extension workers role perception and performance in poultry egg marketing.

\section{Materials and Methods}

\subsection{Sampling Procedure and Sample Size}

Simple random sampling was used in selecting the respondents. The population consisted of small and medium scale commercial poultry farmers, extension workers and agricultural development officers working in the state. Oladele as cited by Oladeebo and Ojo (2012) classified small scale poultry farms as stocking of less than 1,000 birds and medium scale as between 1,000 and 5,000 birds. This classification is different from what is obtainable in developed countries. Ozowa (1997) stated that by international standards whereby all farms less than 10.00 hectares are classed as small, then 94.37 percent of all farm holdings in Nigeria must be classified as small scale farms while the remaining 5.63 percent or 1.7 million are medium scale holdings The extension officers are attached to the Delta State Agricultural Development Project while the agricultural development officers work in each of the 25 Local Government Councils. In this study both the agricultural extension agents and community development officers were regarded as playing identical roles and hence they are commonly named "extension workers". The population of the small and medium scale poultry farmers was five hundred and twenty six (526). The population of the extension agents and community development officers was one hundred and five (105), and one hundred and thirty (130) repectively. Twenty per cent (20\%) entrepreneurs of the small and medium poultry farms which corresponded to one hundred and five (105) were randomly selected across the state. Twenty per cent (20\%) each of the extension agents and community development officers which corresponded to 21 and 26 respectively were randomly selected. Thus the sample was made up of one hundred and five (105) enterpreneurs of poultry farms and forty seven (47) extension workers.

\subsection{Method of Data Collection and Analysis}

Oral interview and structured questionnaire were used for data collection. The oral interview was used for the entrepreneurs of the poultry farms while questionnaire were used for the extension workers. The poultry farmers were asked to indicate the class of people who buy their poultry eggs. The questionnaire measured the production stages at which advisory services were provided to poultry farmers, role perception and role performance in poultry egg marketiing. Eleven (11) statements each were constructed for role perception and role performance for egg marketing (see Table 2). Data were analysed by simple percentage, mean and $t$ test. 


\subsection{Measurement of Variables}

Perceptual statements were measured by yes or no dichotomy. The 'yes' and 'no' responses were scored 1 and 0 respectively. The scores were aggregated for each respondent to make up the perceptual score. Similarly, the respondents were asked to indicate yes and no' for the roles performed and were scored 1 and 0 respectively. The score were also aggregated to make up the role performabce score for each repondents.

\subsection{Conceptual Framework of Analysis}

In this study the roles of extension workers in poultry egg marketing was conceptualised in terms of the role perception and actual role performance (Fig. 3).In rhe first place, the extension workers role perception in poultry egg marketing was measured. Proper role perception would most likely lead to efficient role performance. Tnis agrees with Gibson et.al. (1982) that role perception could have a definite impact on performance. Fig.3 shows that role perception was influenced by factors such as training/education, attitude and value system. Role performance is influenced by organizational goals and supervision, motivation and training/edication. Effective role performance brings about the performance of improved marketing functions among small anf medium scale poultry egg producers. The marketing functions include egg grading, price information, record keeping, transportation, sales timing, stocking of improved layers, resource use efficiency, and planning and market promotion. When farmers are able to perform their marketing functions very well it brimgs about increase income and welfare. This in turn tranxlates to enhance GDP. Ekong (2010) maintained that role refers to responsibility, obligation or expected behaviour attached to any social position. Norman (1982) stated that perception was a process by which people select, organize and interpret sensory stimulation into a meaningful and coherent picture of the world. It is a process which gets structured, organized and modified as the individual matures.

\section{Results and Discussion}

\subsection{Marketing Channels for Poultry Egg}

Eggs were packaged and sold in crates by the producers. The mutually inclusive responses of the poultry producers or poultry farms entrepreneurs on the channels of poultry eggs marketing were presented in Table 1 and represented by Fig. 4.It was found that the predominant channel of egg marketing was through wholesaler $(100.00 \%)$, followed by middlemen/assemblers (78.10\%), retailers (24.76\%) and consumers (9.52\%). Thus it was concluded that the marketing channel for poultry eggs consisted of the producers, middle men/assemblers, wholesalers, retailers and consumers. The retailers and consumers do not often have direct access to the producers (Fig. 4) except in remote in rural markets. In some cases influential consumers drive to poultry farms to purchase eggs in crates for the family use. Dinka et al (2010) found that in most villages in Ethiopia women and children take chicken and eggs to the local market and sell to traders or directly to consumers. Moges and Dessie (2010) found that the role of middle men was significant in chicken and egg marketing system. Depending on the location of the farm dwelling, village chicken owners sold their chicken and eggs either to middle men or directly to consumers. Poultry eggs are sold in large quantities (crates) hence it was difficult for retailers and consumers to transport them within the study area. Although the marketing channel was easy to conceptualise it gave prelude to a discussion of the extension positions and roles in egg marketing in the study area.

\subsection{Positions of Marketing Extension Services for Poultry Egg Production}

The extension workers indicated that they usually advise the farmers about egg marketing at the procurement, development, laying and packaging stages. The frequency of responses to the stages, at which extension workers advise farmers on egg marketing, was represented in Figure 5. The responses were procurement 3(6.38\%), development stage $10(21.28 \%)$, laying stage 30(63.83\%) and packaging 47(100.00\%). Thus it was concluded that the most important stages for advising farmers on egg marketing were the laying and packaging stages. This study is quite unique as no study has been conducted to delineate the progressive stages for advising farmers on poultry egg marketing. Provision of livestock extension services should not be confined to dissemination of proven breeds of poultry and health management practices. Efficient marketing is important because it enables the farmers to realise the gains of his labour. To this end, issues of poverty alleviation, rural welfare and income should be made prominent in agricultural extension delivery.

Tiraieyari et al (2010) noted that technology transfer was the main challenge of agricultural extension agents. 
There is a looming evidence of change from the traditional transfer of technology approach as exemplified by the Farmer Field School and other participatory extension approaches. Agricultural extension services such as agricultural marketing and market information, credit mobilisation, home making, rural hygiene and sanitation practices could improve the fortune of the farmer. Karbasioun, (2007) and Worth (2006) observed that the role of agricultural extension agents was gradually changing from transferring knowledge and technology to that of consultants, advisors and facilitators of the farmer learning process. Ozowa (1997) reported that in Nigeria, agricultural market information to small scale farmers was provided by the Ministry of Agriculture through the field level extension workers and by the broadcasting media. A lot still needed to be done in the provision of market information. He further noted that information provided under the extension programme was exclusively focused on policy makers, researchers, and those who manage policy decisions with scant attention paid to the information needs of the targeted beneficiaries of the policy decisions. The lack of effects of agricultural policies and programmes on the intended beneficiaries contradict the pristine objectives and participatory characteristics of agricultural extension services.

\subsection{Role Perception in Poultry Egg Marketing by Extension Workers}

Table 2 contains responses to both role perception and performance of egg marketing by extension workers in the study area. The extension workers did not perceive advice on egg grading 13(27.66\%), planning and market promotion 10 (21.28\%), price forecasting $10(21.28 \%)$, and sales timing 15 (31.91\%) as their roles based on the percentage response. However, they perceived advise on available market for poultry eggs 35 (74.47\%), provision of price information 47(100.00\%), advise on poultry egg transportation 40 (85.11\%), advise on resource use efficiency for maximum profit 47 $(100.00 \%)$, packaging function $47(100.00 \%)$, and advise on proven egg layers $47(100.00 \%)$ as important roles which they should render to poultry egg producers as extension agents.

The poor role perception of extension workers about egg marketing could be attributed to the lack of understanding of the dragnet of agricultural extension and the limitation imposed by the transfer of technology model of agricultural extension. The agricultural extension service is no longer restricted to transfer of proven technologies as perceived by most extension workers. According to Bello and Salau (2009) agricultural extension referred to an education system that provide farmers with technical advice required to increase farm output and income including advice on credit, other inputs and marketing. It also provided research institutes and credit institutions information about farmer's conditions. In the view of Gibson et al. (1982), role perception could have a definite impact on performance. It should be noted that advice on egg grading, planning and market promotion, price forecasting, and sales timing are integral part of marketing extension which extension workers should not relegate in the performance of their duties.

\subsection{Role Performance in Poultry Egg Marketing by Extension Workers.}

In Table 2, role performance by the extension workers in poultry egg marketing was poor with regards to egg grading $2(4.26 \%)$, advise on available markets for poultry eggs $7(14.89 \%)$, advise on poultry egg transportation $11(23.40 \%)$, advise on resource use efficiency for maximum profit $0(0.00 \%)$, planning and market promotion $1(2.13 \%)$, price forecasting $1(2.13 \%)$ and sales timing 2 (4.26\%). The level of role performance among the extension workers was good in terms of provision of price information to poultry egg producers $26(55.32 \%)$ packaging $38(80.85 \%)$, and advise on stocking proven egg layers 45 (95.74\%). More than ever before, there is need for extension workers to be more effective and appreciative of the scope of agricultural extension particularly in egg marketing. This hinges on the fact that agricultural extension service is a holistic institutional framework design for emancipating the farmers from poverty, and solving the myriads of farm level and rural community problems. In the present age apparently dominated by communication and communication strategies farmers need information to boost sales and derive maximum benefits from their farming endeavour. Ozowa (1997) stated that market information needs of small scale farmers included: information on product planning; information on current prices; information on forecast of market trends-this type of information assists farmers in planning their market products; information on sales timing to avoid market glut; information on improved marketing practices; and information on group marketing. Moges and Dessie (2010) found that the price of chicken and eggs varied between months of the year and were determined by a number of driving factors. Some of the identified factors affecting prices of chicken products were; demand and supply of chicken products, agroecology (market access), product type (sex, age, breed, comb type), season of the year (dry and rainy), market type (urban versus local markets), market day types (holyday versus ordinary market days) and fasting seasons (for example, pre-Easter fasting season). It is pertinent for extension workers to be well abreast of the factors affecting egg marketing 
to enable them give the relevant advice to the farmers.

\subsection{Relationship between Role Perception and Role Performance in Poultry Egg Marketing}

The relationship between role perception and performance were compared using the respondents' scores on the eleven items (Table 3). There was a significant difference between total scores on role perception and role performance scores on the eleven (11) extension roles in egg marketing $(t=19.892 ; p<0.01)$. Agricultural extension borrows a lot from marketing as could be gleaned from the stages of adoption. Many researchers including Williams et. al (1984), Rogers (2003) and Vijayabhinandana (2007) agreed that adoption of agricultural innovations followed five-fold hierarchical or pyramidal stages namely awareness, interest, evaluation, trial and adoption ( Figure 6) Separate marketers were not employed to carry out the function of egg marketing advisory services in the study area. A paradigm shift is important to ensure that poultry egg farmers are equipped by extension workers with relevant market information necessary for effective marketing. A significant difference between role perception and performance was found in the advisory services on egg grading ( $t=3.749 ; p<0.01)$, advise on available markets for poultry eggs $(t=8.233 ; p<0.01$ ), provision of price information $(t=6.095 ; p<0.01)$, Advise on poultry egg transportation $(t=8.609 ; p<0.01)$, advise on resource use efficiency for maximum profit $(t=25.974 ; p<0.01$ ), egg packaging $(t=3.391 ; p<0.01)$, advise on planning and market promotion $(t=3.391 ; p<0.01)$, price forecasting $(t=3.391 ; p<0.01)$, sales timing $(t=4.194 ; p<0.01)$, and advise on record keeping $(t=6.362 ; p<0.01)$. There was no significant difference between role perception and role performance in advisory services on stocking proven egg layers $(t=1.430 ; p>0.05)$. The latter finding is not surprising because agricultural extension has been predominantly tailored towards the dissemination of new technologies without considering the markets and marketing of agricultural products. To the poultry egg producers, efficient marketing is the DNA of the entire production process. Without efficient marketing the farmers efforts would be futile. Swanson and Rajalahti ( 2010) maintained that the technology transfer model of extension was prevalent during colonial times and reemerged with intensity during the 1970s and 1980s when the Training and Visit (T\&V) system was established in many Asian and Sub-Saharan African countries. They admonished that agricultural development goals should go beyond the primary focus on technology transfer in the twentieth century. They maintained that in addition to transferring new technologies in this modern era, priority should be given to increasing farm incomes, maintaining national food security, empowering farmers by building social capital within rural communities, training farmers to use sustainable natural resource management practices and improving rural livelihoods. From the foregoing, it could be argued that the success of the farmer depends on both the new technology and market incentives.

\section{Conclusion}

The marketing channel for poultry eggs were wholesalers, middle men/ assemblers and retailers. Marketing advisory services should be provided to poultry egg producers at the procurement, development, laying and packaging stages of production. The extension workers did not perceive advisory services on egg grading, planning and market promotion, price forecasting, and sales timing as their roles. The extension workers performed their roles poorly with regards to egg grading, advise on available markets for poultry eggs, advise on poultry egg transportation, advise on resource use efficiency for maximum profit, planning and market promotion, price forecasting, and sales timing. The extension workers were able to perform their roles only on provision of price information to poultry egg producers, packaging, and advise on stocking proven egg layers. There was a significant difference between total scores on role perception and role performance on the eleven (11) extension roles in egg marketing. Extension workers do not performed their roles in egg marketing. Efficient marketing is important in the overall success of the poultry egg producer. The role of extension workers in poultry egg production should go beyond the traditional transfer of proven layers to encompass the various egg marketing functions in order to improve the welfare of the poultry egg producers. Improved welfare and income of the farmer is paramount in the research efforts of the rural extension worker.

\section{References}

Adegeye, A. J. and Dittoh, J. S. (1982). Essentials of Agricultural Economics. Ibadan: Centre for Agricultural and Rural Development Bello, M. and Salau, E.S 2009. A case for Participatory (cost sharing) approach to agricultural extension in Nigeria. Journal of Agricultural Extension 13(1) 84-89

Benson, A. and Jafry, T. 2013. Reaching rural women: understanding the term gender sensitivity in agricultural extension. American International Journal of Social Science, 2(5):17-25 
Dinka, H., Chala, R., Dawo, F., Bekana, E. And Leta, S. 2010. Major Constraints and Health Management of Village poultry production in rift valley of Oromia, Ethiopia, American-Eurasian J. Agric. \& Environ. Sci., 9 (5): 529-533, 201

Ekong, E. E 2010, Introduction to Rural Sociology, Dove Educational Publishers, Uyo, Nigeria.

Food and Agriculture Organization, FAO 2013. Egg packaging transport and storage. Retrieved on $10^{\text {th }}$ August 2013 from http//www.fao.org/documents/en/docrep.jsp. ;jsessionid=34C0605795B79B6F3A00BCEE9DB3AD95

Food and Agriculture Organization, FAO, 2013. Marketing Extension. Retrieved on 7th October 2013 from http://www.fao.org/ag/ags/agricultural-marketing linkages/marketing-extension/en/

Gibson J. L; Ivanecevih, J. M, and Donnelly, H. J. 1982. Organization: behaviour, structure and Process. Plano, Texas Businesses Publication Inc.

Karbasioun, M., 2007. Towards a competency profile for the role of instruction of agricultural extension professionals in Esfahan. PhDthesis, Social Sciences Group, Chair Group of Education and Competence Studies, Wageningen University and Research Centre, The Netherlands.

Moges, F. and Dessie, T. 2010. Characterization of village chicken and egg marketing systems of Bure district, North-West Ethiopia. Livestock Research for Rural Development Newsletter, 22 (10)

Mohammed, A. B., Mohammed, S. A., Ayanlere, A. F and Afolabi, O. K (2013) Evaluation of Poultry Egg Marketing in Kuje AreaCouncil Municipality of F.C.T Abuja, Nigeria Greener Journal of Agricultural Sciences 3(1): 068-072

Norman, G.,Harlow, H. F., Jones, L. V. And Stevenson, H. W. (1982). Occupational Strss: Coping and Health Problems of Teachers. The Journal of School Health, 51: 175-181

Ogunfiditimi, T. G. and Ewuola, S. O. 1995. The Synthesis of Comparative of Agricultural Extension Systems. Ibadan: Emmi Press Ltd

Oladeebo, J. O and Ojo, S. O. 2012. Economic appraisal of small and medium scale performance in poultry egg production in Ogun State, Nigeria. African Journal of Agricultural Research, 3(37: 5170-5174

Olaitan, S. O. 1984. Agricultural Education in the Tropics. London : Macmillan Publishers

Ovwigho, B. O. and Ifie, P. A. 2009. Principles of Youth Development in Africa. Benin-City: Ethiope Publishers

Ozowa, V. N. 1997 Information needs of small scale farmers in Africa: The Nigerian Example. Consultative Group on International Agricultural Research, CGIAR Newsletter (4) 3

Swanson, B. E. 2008. Global Review of Good Agricultural Extension and Advisory Services. Rome: FAO

Swanson, B. E. and Rajalahti, R. (2010). Strengthening Agricultural Extension and Advisory Services: Procedures for Assessing, Transforming and Evaluating Extension Systems. Agriculture and Rural Development Discussion Paper No. 44. Washington D. C: The World Bank

Tiraieyari, N., Khairuddin, I., Hamzah, A and Jegak, U. 2010. Importance of programme development competencies for agricultural extension. American Journal of Agricultural and Biological Sciences, 5 (3): 376-379

Technical Centre for Agricultural and Rural Cooperation, CTA (2007). Instant Market Linkage. Spore. No. 128, pp.3

Technical Centre for Agricultural and Rural Cooperation, CTA 2011. Three Steps Towards Modernisation of Agriculture. Spore: Special Edition, August, 2011, pp. 18-22

Technical Centre for Agricultural and Rural Cooperation, CTA 2013. Trading up and empowering and empowering farmers. Spore Special Edition, August 2013, p. 32 \& 4

United States Agency for International Development, USAID (2011). Rural Extension and Advisory Services. USAID Agriculture

Vijayabhjinandana, B. 2007. Communication and Diffusion of Agricultural Innovations', National Institute of Agricultural Extension Management, Pradesh, India

Williams, S. K. T., Fenley, J. M. and Williams, C. E. 1984,. A Manual for Agricultural Extension Workers in Nigeria, Les Shyraden, Ibadan.

Worth, S., 2006. Agriflection: A Learning Model for Agricultural Extension in South Africa. Journal of Agricultural Education and Extension, 12(3):179-193.

Table 1: Responses to marketing channels for poultry eggs

\begin{tabular}{clc}
\hline S/N & \multicolumn{1}{c}{ Channel } & Frequency/per cent \\
\hline 1 & Middle men/ assemblers & $82(78.10)$ \\
2 & Wholesaler & $105(100.00)$ \\
3 & Retailers & $26(24.76)$ \\
4 & Consumers & $10(9.52)$ \\
\hline
\end{tabular}

Table 2: Responses to role perception and performance in egg marketing by extension workers

\begin{tabular}{clccc}
\hline S/N & \multicolumn{1}{c}{ Statement } & $\begin{array}{c}\text { Role Perception } \\
\text { Freq/per cent }\end{array}$ & $\begin{array}{c}\text { Role Performance } \\
\text { Freq/per cent }\end{array}$ & Remarks \\
\hline 1 & Advise on egg grading & $13(27.66)$ & $2(4.26)$ & P 1, P 2 \\
2 & Advise on available markets for poultry eggs & $35(74.47)$ & $7(14.89)$ & $\mathrm{G} \mathrm{1,P} \mathrm{2}$ \\
3 & Provision of price information & $47(100.00)$ & $26(55.32)$ & $\mathrm{G} \mathrm{1,} \mathrm{G} \mathrm{2}$ \\
& & & &
\end{tabular}


$4 \quad$ Advise on poultry egg transportation

5 Advise on resource use efficiency for maximum profit

6 Packaging function

$7 \quad$ Planning and market promotion

8 Price forecasting

9 Sales timing

10 Advise on stocking proven egg layers

11 Advise on record keeping

\section{NB:}

Above $50 \%=$ good, below $50 \%=$ poor

$\mathrm{P} 1=$ poor role perception

$\mathrm{P} 2$ = poor role performance

$\mathrm{G} 1=\mathrm{Good}$ role perception

$\mathrm{G} 2=\mathrm{Good}$ role performance

$\begin{array}{ccc}40(85.11) & 11(23.40) & \text { G 1, P } 2 \\ 47(100.00) & 3(6.40) & \text { G 1, P } 2 \\ 47(100.00) & 38(80.85) & \text { G } 1 \text { G } 2 \\ 10(21.28) & 1(2.13) & \text { P 1 P } 2 \\ 10(21.28) & 1(2.13) & \text { P 1 P 2 } \\ 15(31.91) & 2(4.26) & \text { P 1 P 2 } \\ 47(100.00) & 45(95.74) & \text { G 1 G } 2 \\ 47(100.00) & & \end{array}$

$1, P 2$

$1, P 2$

$1 \mathrm{G} 2$

$1 P 2$

$1 P 2$ $47(100.00)$

Table 3: Comparison of role perception and performance of extension workers

\begin{tabular}{clccccc}
\hline S/N & \multicolumn{1}{c}{ Variables } & $\begin{array}{c}\text { Mean } \\
\text { Perception }\end{array}$ & $\begin{array}{c}\text { Mean } \\
\text { Performance }\end{array}$ & Std. error & $T$ & T.sig \\
\hline 1 & Advise on egg grading & 0.2766 & 0.0426 & 0.06243 & 3.749 & 0,000 \\
2 & Advise on available markets for poultry eggs & 0.7447 & 0.1489 & 0.07236 & 8.233 & 0.000 \\
3 & Provision of price information & 1.000 & 0.5532 & 0.07330 & 6.095 & 0.000 \\
4 & Advise on poultry egg transportation & 0.8511 & 0.2340 & 0.07167 & 8.609 & 0.000 \\
5 & Advise on resource use efficiency for maximum profit & 1.000 & 0.0638 & 0.03604 & 25.974 & 0.000 \\
6 & Egg packaging function & 1.000 & 0.8085 & 0.05801 & 3.391 & 0.002 \\
7 & Planning and market promotion & 0.2128 & 0.0213 & 0.05801 & 3.391 & 0.002 \\
8 & Price forecasting & 0.2128 & 0.0213 & 0.05801 & 3.391 & 0.002 \\
9 & Sales timing & 0.3191 & 0.0426 & 0.06596 & 4.194 & 0.000 \\
10 & Advise on stocking proven egg layers & 1.000 & 0.9574 & 0.02976 & 1.430 & 0.160 \\
11 & Advise on record keeping & 1.000 & 0.53190 & 0.07357 & 6.362 & 0.000 \\
12 & Overall & 7.6170 & 3.36187 & 0.21392 & 19.892 & 0.000 \\
\hline
\end{tabular}

Fig. 2: Generalized distribution channels for foodstuffs.

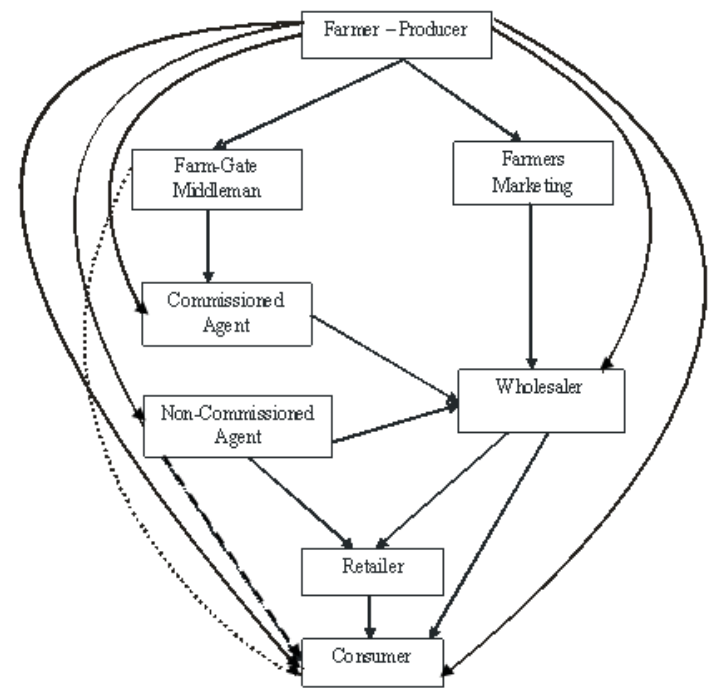

Source: Adegeye and Dittoh (1982). Essentials of Agricultural Economics 
Fig.3: Conceprual Framework of Analysis

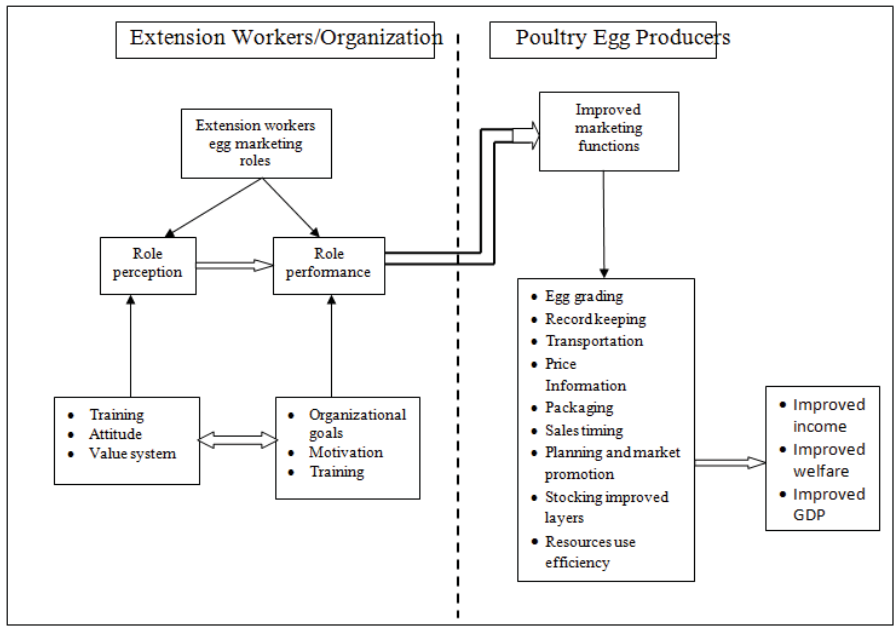

Fig. 4: Marketing Channels for poultry meat and eggs

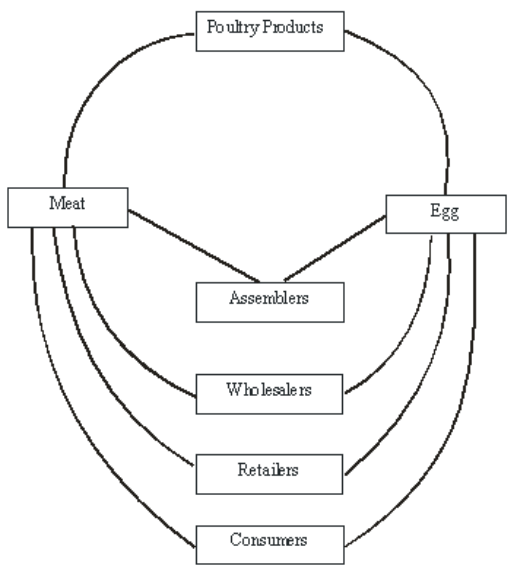

Fig. 5: Stages for Advising Poultry Farmers on Egg Marketin

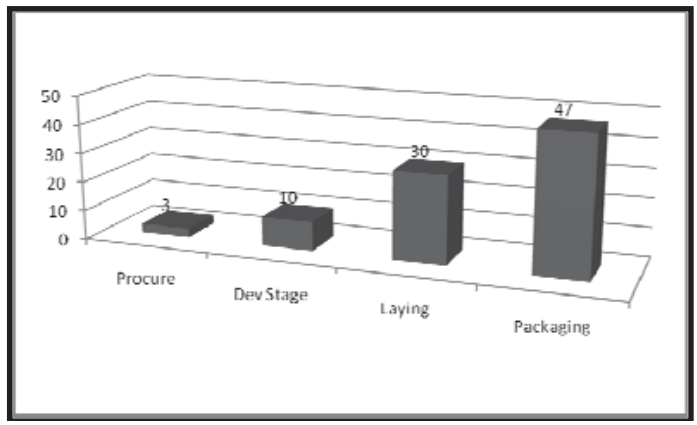


E-ISSN 2039-2117

ISSN 2039-9340

Fig 6: Stages of adoption
Vol 5 No 2

January 2014

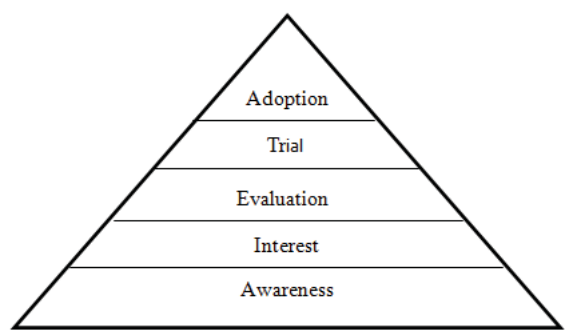

